\title{
To Dokumenter vedkommende Tyreholdet i Stendrup By i det 16de Aarhundrede.
}

Meddelte af ('and. jur., Proprieter Thygesen af Lykkesgraard ved Kolding, tidligere af samme i $\mathbf{1 8 8 5}$ medilelte til Sanlinger til jydsk Histurie og Tojograti.

\section{Aar 1575.}

(Originalerne berares paa Stenderuygaard.)

$V_{i}$ efterskrevne Magnus Jørgensen i Stubbum, Herredsfoged i Tyrstrup Herred, Iver Pedersen i Stubbum, Hans Dinsen i Gammelby, Sandemænd i forskievne Herred, kundgjøre, at Aar efter Christi Fødsel 1575 den Tirsdag næst før St. Hanslag Midsommer, da var skikket for os og menige Herredsmænd, som den Dag Ting søgte, beskeden Dannesvend Jens J.edersen i Stendrup *) Sandemand, bedes, fik og fremledte et fuldt Tingsvinde af otte trofaste Dannemænd, som vare Jørgen Iversen i Sigling, Peder Jepsen i Hvindrun, Jep Markvardsen, Jens Persen i Bjert Nis Mikkelsen, Jes Nielsen i Hejls, Jey Knudsen i Yonsild og Jørgen Hansen i Simmersted, livilke forskrevne otte Dannemænd udginge og velberaadte igjen indkomne, vunde alle samdregtelig paa Tro, Sjæl og Sandhed, at de forskrevne Dag saa og løørte, at blev vunden inden Ting, at alle Stendrup Bymænd var bleven tilens med hverandre

*) et af de inkorporerede slesvigske sugne. 
om tre Tyre at holde baade Vinter og Sommer, og det Stykke Eng, som haver været dertil af Arilds Tid, som kaldes Tyre-Mader, det skal blive dertil, som det haver været, item efterdi at samme Eng er ikke nok til at holde tre Tyre udaf, da haver hver Mand i Byen bevilliget, at der skal udlixgges en Ager udi Trind Lykke fra Byen og ud til Loftskou Dam(?) over hver Mands Jord otte Alen bred, saa den kan erjes (pløjes) otte Alen bred ud fra Gaarden, og skal samme forskrevne Eng og Jord skiftes udi tre Parter mellem de tre Mænd, som Tyrene holder, saa at den ene kan ske saa godt Skjel som den anden; ydermere blev det ogsaa talet, at saamange Køer, som hver Mand haver flere end fire til hver Otting, dem skulde de give 2 Sk. lübs. af hver Ko og Inderster to Skilling lübs. af hver $\mathrm{Ko}$, thi de læggger ingen Jord ud; men Præsten skal være fri uden med den Ager, som forskrevet staaer; der skal de bruge tvertover hans Jord ligesom over de andre Bymænds, som forbemeldt er. Item skal og alle 3 Tyre folge Hjorden on Sommeren, men om Vinteren maa de skifte dennom det imellem enten efter Ottingstal eller efter Køerne, som hver Mand haver til; men kunne de ikke selv enes derom, da skal tolv af de reldste Bymænd sige dem det imellem, det skal være tre Irænd af hver Fjerding. Item skal samme tolv Mænd sige paa, om der klages, at Tyrene ikke vare enten saa skikkelige eller saa fødte, som der sig burde; da skulle de lægge andre dertil, som dennem baade kunne og ville fosde og holde, som det sig burde og ret kunde være. Item blev og saa talet, at ingen Mand skal have mere Kræ til Græs om Sommer end som han kan føde om Vinteren paa sit eget Foder, fordi at de kan ikke lægge deres Græsgang 
par dette Enemærke, og paa det sidste blev det ogsaa "gcluderitt", at hvilken som ikke vilde holde alle forskrevne Punkter, thi det er hver Mands Garn, da skal han give min naadigste Herre 1 Gulden og Lehnsmand 1 Mark og Fogden en Mark lüb. og alle Bymænd en Tønde Øl. Datum ut supra.

\section{6.}

Vi efterskrevne, Peder Pedersen i Strarup, Herredsfoged i Tyrstrup Herred, Hans Dinsen i Gammelby og Jens Nielsen i Sjølund, Sandemænd i samme Herred, evindelig med Gud kundgjøre vi, at Aar efter Christi Fødsel 1586, Tirsdag, som var den 31te Maj, da var skikket for os og menige Herredsmænd, som den Dag Ting søgte, ærlige Dannesvend Jens Pedersen i Stendrup, Sandemand i forskrevne Herred, der da bedes, fik og fremledte et fuldkomment Tingsvinde af 8 trofaste Dannemend, som vare Laue Kock i Groninghoj (Grønninghoved), Jerk Persen, Jens Andersen i Sjglund, Iver Nielsen, Jerk Jespersen i Heils, Eskel Gregersen, Hans Nielsen i Vorgaard og Knud Pedersen i Bigvra $(?)^{*}$ ), hvilke forskrevne 8 Dannemænd udginge og velberaadte igjen inclkomme, vuncle og sagde paa deres gode Tro, Sjæl og Sandhed, at de saa og hørte inden Tyrstrup Herreds fire Tingstokke for Dom og Ret, at Jens Persen i Stendrup lod læse en Grand-Vide inden Tinge; som Stendrup Bymænd lavde alle vedtagen, som var udgiven i det Aar, som man da skrev 1575, Tirsdagen næst for St. Hans Dag Midsommer, udi hvilken Grandvide de havde vedtagen at holde 3 Tyre i Stendrup $\mathrm{By}$, og var benærnt, hvad de skulde have derfor, som dennem

*) I et andet Dokument niernes Bygrraa. 
holdt, og sar havde de veltagren, at Ingen i Stendrup skulde have mere Kiræ til Græsning om Sommeren, end som han kunde fode paa hans eget Forindh on Vinter og derpaa berjærede Jens Pedersen i Stendrup en Dom af Peder Pedersen Herredsfoged, om de burde ikke at holde samme Grandvide, som er vunden og bestanden inden Tinge og "forseldh" (forseglet). Da efter slig Bevist og ng efter deres egen Grandvide og Vedtrgt, da fandt Peder Pedersen Herredsfoged de Stendrup Bymænd til at holde saavidt som deres eget udgivne Brer og Segl formelder og indeholder og imedens samme Breff og Segl og Grandvide stander red sin fulde Magt, som Stendrup Grand- og Bymænd haver selv vedtagen at holde. Actum ut supra. 